\title{
DIKSI DALAM POLA ASUH ANAK YANG ISLAMI
}

\author{
Oleh : \\ Siti Mutmainah \\ IAI Al - Falah As - sunniyyah Kencong \\ mutmainahsiti88@yahoo.com
}

\begin{abstract}
Parents must set an example for their children both their behavior and speech. In this study emphasized on speech or ways of speaking parents who must use language that is good in communicating with children, because language is very influential in children's growth and development. One good use of language is to choose the right diction. Choosing the right diction in a discourse will make it easier for the reader or opponent to catch the meaning of the writer or speaker. This theory also applies to parenting. In the Quran the advice of parents to children is exemplified in Lukman's letter, and there are also diction which can be studied in it.
\end{abstract}

Keywords: parenting, advice, diction.

\begin{abstract}
ABSTRAK
Orang tua harus menjadi teladan bagi anak-anaknya baik tingkah laku dan ucapannya. Dalam penelitian ini ditekankan pada ucapan atau cara berbicara orang tua yang harus menggunakan bahasa yang baik dalam berkomunikasi dengan anak, karena bahasa sangat berpengaruh dalam tumbuh kembang anak. Salah satu penggunaan bahasa yang baik yaitu dengan memilih diksi yang tepat. Pemilihan diksi yang tepat dalam suatu wacana akan mempermudah pembaca atau lawan tutur untuk menangkap makna dari penulis atau pembicara. Teori ini juga berlaku dalam mengasuh anak. Dalam Al-Quran nasihat orang tua terhadap anak banyak dicontohkan dalam surat Lukman, dan juga terdapat diksi yang dapat dikaji di dalamnya.
\end{abstract}

Kata kunci: pola asuh, nasihat, diksi.

\section{A. Pendahuluan}

Orang tua memiliki tanggung jawab yang besar terhadap anaknya. Hal ini dikarenakan anak merupakan amanah yang diberikan Allah SWT. Menjadi orang tua juga merupakan anugerah dari Allah, karena tidak semua orang memiliki kesempatan yang sama untuk menjadi orang tua. Karena itulah sudah sepatutnya orang yang memiliki anak harus bersyukur dan membawa masa depan anak-anaknya agar menjadi manusia yang berguna bagi agama, bangsa dan negara.

Dalam Islam, sejak kecil anak sudah seharusnya dikenalkan dengan tauhid bahkan sejak dalam kandungan agar mereka mencintai Allah dan Rosullullah. Mengingat fase kanak-kanak Vol.DI. No.TZ. April 2019

Jurnal Auladuna | 1 


\section{Siti Mutmainah}

merupakan saat yang tepat bagi pembinaan dan pendidikan. Salah satu cara yaitu dengan menjadi teladan yang baik karena fitrah dari anak adalah meniru. Dalam hal ini orang tua yang setiap hari ditemui anak-anaknya yang harus menjadi teladan bagi anak-anak baik tingkah laku dan ucapannya.

Kesimpulan dari penelitian yang dilakukan oleh seorang psikolog anak menyatakan bahwa lebih dari 90\% permasalahan anak disebabkan oleh kesalahan atau ketidaktahuan orang tua akan cara berkomunikasi dan penyampaian nilai yang baik terhadap sang anak. ${ }^{1}$ Penelitian tersebut membuktikan bahwa orang tua harus menggunakan bahasa yang baik dalam berkomunikasi dengan anak. Bahasa ibu adalah bahasa yang pertama kali didengar dan ditiru oleh anak. Karena itu orang tua harus menghindari ucapan atau bahasa yang buruk dan mengandung makna negatif seperti makian dan ejekan.

Dapat disimpulkan Bahasa juga sangat berpengaruh dalam tumbuh kembang anak. Bahkan di dalam Al-Quran banyak dicontohkan kata-kata nasihat untuk anak seperti dalam surat lukman berikut:

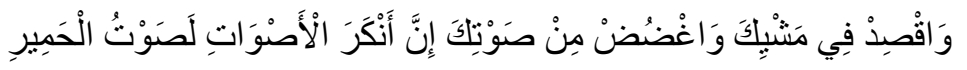

"Dan sederbanalab kamu dalam berjalan dan lunakekanlah suaramu. Sesunggubnya seburuk-buruk suara ialah suara keledai." (QS. Lukman: 19).

Dalam ayat tersebut menjelaskan bahwa salah satu akhlak mulia yang diajarkan oleh Lukman kepada anaknya mengenai sikap tawadhu' dan bagaimana beradab di hadapan manusia. Di antara yang dinasehatkan Lukman Al Hakim adalah mengenai adab berbicara, yaitu janganlah berbicara keras seperti keledai.

\section{B. Peran/Kewajiban Orang Tua terhadap Anak}

Setiap orang tua berkewajiban untuk merawat anak-anaknya karena anak adalah titipan dari Allah kepada orang tua. Sudah seharusnya orang tua memelihara dan mengasuh anak dengan baik sesuai dengan amanah yang diberikan Allah. Anak akan tumbuh dengan memiliki sifat-sifat yang baik dalam pemeliharaan dan pengasuhan yang baik.

Kesalahan dalam pola asuh anak akan menyebabkan anak akan berdampak buruk bagi anak. Butuh kesadaran orang tua mengartikan pengasuhan anak dengan tidak memperlakukan anaknya sebagai hak milik yang bisa diperlakukan sesuka hati. Padahal, anak juga merupakan

\footnotetext{
${ }^{1}$ Ahmad, Ukasyah Habibu. Didiklah Anakmu Ala Rasulullah. 2015.(Yogyakarta: Saufa) hal. 183

2 | Jurnal Auladuna

Vol.DI. No. [Z2. April 2019
} 
manusia yang memiliki perasaan dan keinginan yang perlu diperhatikan. Begitu pula orang tua, mereka mempunyai beberapa kewajiban tertentu yang harus dipenuhi kepada anak. Kewajiban orang tua kepada anak yaitu: ${ }^{2}$

\section{Menjadi orang tua yang baik}

Peran orang tua dalam mendidik anak memang sangat penting untuk membentuk anak yang berbudi dan berakhlak baik. Sebagai orang tua, kita tidak langsung tahu bagaimana cara menjadi orang tua yang baik untuk anak karena tidak ada panduan yang baku mengenai hal tersebut. Kita hanya bisa berusaha mendidik anak sebaik-baiknya dengan mengajarkan nilai kehidupan yang baik kepada anak.

\section{Memberikan nama yang bagus untuk anak}

Pemberian nama yang mengandung arti baik sangat penting bagi seorang anak sebagaimana disebutkan dalam hadits berikut ini:

"Dari Samurah bin Jundap berkata bahwa sabda Rasulullah adalah sebagai berikut: Anak tergadai dengan aqiqahnya, disembelib pada hari ke tujub sebagai tebusannya, diberi nama serta dicukur kepalanya pada hari itu" (HR. Tirmidzi)

Karena itu para orang tua harus memperhatikan dengan seksama nama yang akan diberikan kepada anaknya masing - masing. Apakah arti nama itu benar - benar mengandung kebaikan atau justru merupakan nama yang mengandung arti kurang baik.

\section{Memberikan air susu ibu kepada anak}

Air susu ibu telah terbukti dalam banyak penelitian bahwa mengandung sangat banyak manfaat bagi pertumbuhan anak selama dua tahun pertama. Dalam salah satu ayat Al Qur'an pun telah menyebutkan dengan jelas mengenai hal ini:

"Para ibu hendaknya menyusukan anak - anaknya selama dua tabun penub yaitu bagi ibu yang ingin menyempurnakan penyusuan. Dan ada kewajiban ayah untuk memberi makan dan pakaian kepada ibu dengan cara ma'ruf. Seseorang tidak diberi beban selain menurut kadar kesanggupannya. Janganlah seorang ibu menderita kesengsaraan karena anaknya dan seorang ayah karena anaknya pula, dan abli warispun juga memiliki kewajiban demikian. Dan jika keduanya ingin menyapib sebelum dua tabun dengan kerelaan dan permusyawaratan, maka tidak ada dosa bagi keduanya. Dan jika kamu ingin anakmu

\footnotetext{
${ }^{2}$ Ibid, hal. 86

Vol.DI. No.D2. April 2019

3 | Jurnal Auladuna
} 


\section{Siti Mutmainah}

disusukan oleb orang lain, tidak ada dosa bagimu bila kamu membayar dengan patut. Bertakwalab kamu kepada Allab dan ketahuilah bahwa Allah Maha Melibat.” (Al Baqarah: 233)

Jika karena satu dan lain hal ibu tidak bisa memberikan air susu kepada anak, maka tidak ada masalah untuk menggunakan ibu susu yang berakhlak baik dan dibayar dengan sepatutnya. Namun masalah menggunakan ibu susu ini harus dikaji lebih jauh lagi, tidak bisa dilakukan secara serampangan.

\section{Mengajarkan agama kepada anak}

Pendidikan agama dalam keluarga adalah hal yang paling penting untuk ditanamkan kepada anak sejak dini. Peran ayah dalam keluarga dan peran ibu dalam keluarga adalah untuk mengajarkan agama secara tepat kepada anak. Bila ayah atau ibu belum memiliki pengetahuan yang mendalam mengenai agama, cara mendidik anak dalam agama bisa dimulai ketika anak diajarkan mengenai hal-hal yang mendasar terlebih dulu seperti shalat lima waktu, berpuasa, bersedekah dan hal-hal yang menyangkut kehidupan beragama sehari-hari.

\section{Memberi nafkah}

Salah satu kewajiban orang tua kepada anak adalah memberi nafkah yang mencukupi untuk kehidupan sang anak. Nafkah yang diberikan oleh ayah akan berguna untuk menyokong kebutuhan sang anak selama masa pertumbuhannya seperti makan, minum, pendidikan, pakaian dan berbagai kebutuhan dasarnya yang lain.

\section{Memberi makanan halal}

Pemberian orang tua kepada anak haruslah berasal dari hasil usahanya yang halal dan dengan sumber nafkah yang baik. Membiasakan anak untuk mengonsumsi makanan yang halal, memperoleh penghasilan halal dan membelanjakan uangnya dengan cara yang halal maka akan tumbuh dengan sikap yang sederhana, jauh dari bahaya bersikap boros dan pelit.

\section{Menikahkan anak dengan calon yang baik baginya}

Bila anak Anda telah memasuki usia dimana ia siap menikah, maka nikahkanlah anak sebagai cara menghindari zina bagi remaja dan kawula muda dan cara menghindari pergaulan bebas antara muda mudi zaman sekarang. Anak muda seringkali memilih pacaran sebagai cara memilih pendamping hidup, namun pacaran menurut Islam sebenarnya sangat tidak dianjurkan karena akan mengarah kepada perbuatan zina dan akan mengalami akibat pergaulan bebas tersebut. Nikahkanlah anak jika telah menemukan calon suami atau istri yang benar - benar baik dan cocok untuk mendampingi anak dalam rumah tangga yang menuju keluarga sakinah mawadah warahmah. 


\section{Bersikap adil}

Adil dalam pemberian kepada anak sangat dianjurkan agar tidak ada anak yang merasa dibedakan atau merasa ada penyebab orang tua pilih kasih terhadap anaknya. Bagaimanapun semua anak memiliki hak yang sama terhadap pemberian orang tua. Karena itu perlakukanlah semua anak Anda dengan adil dan sama.

\section{Mengkhitan anak laki - laki}

Ketika mencapai usia tertentu, seorang anak laki - laki akan memasuki waktunya dikhitan atau disunat. Sebenarnya tidak ada batasan usia yang baku mengenai kapan waktu yang cocok untuk anak dikhitan, semua itu tergantung kepada kondisi dan kesiapan anak. Kewajiban mengkhitankan anak tercantum dalam hadits berikut:

"Dari Abu Hurairah mengenai sabda Nabi, yaitu beliau bersabda bahwa: Fitrah itu ada lima, atau lima dari fitrah yaitu pertama adalah khitan, kedua mencukur rambut kemaluan, ketiga memotong kuku, keempat mencabut bulu ketiak, dan kelima adalab memotong kumis.” (HR. Muslim)

\section{Memberi pendidikan yang baik}

Peran keluarga dalam pendidikan anak terutama orang tua adalah untuk mendidik anak dengan sebaik - baiknya menurut nilai - nilai kehidupan yang baik yang telah mereka ketahui. Hal ini tentu berguna agar anak kelak tumbuh menjadi pribadi yang memiliki ciri - ciri orang baik hati dan memahami ajaran agama dengan baik sehingga bisa melandasi kehidupannya dengan pengetahuan agama.

\section{Memberikan kasih sayang}

Rasulullah SAW mengajarkan untuk mendidik anak dengan cinta dan kasih sayang. Karena itulah para orang tua berkewajiban mendidik anak dengan mempertimbangkan aspek kasih sayang kepada anak, dan bukan mendidik anak dengan kekerasan.

Secara garis besar, beberapa kewajiban orang tua kepada anak di atas dapat dijadikan acuan bagi para orang tua dalam mendidik anak. Kewajiban orang tua terhadap anak menurut Islam ini dapat membimbing orang tua agar tujuan yang diinginkan ketika membesarkan anak dapat tercapai dengan sukses.

\section{Nasihat Orang Tua terhadap Anak dalam Al Quran}

Nasihat orang tua pada anak dalam Al-Quran banyak ditemukan di surat Lukman. Luqman Al-Hakim adalah sosok teladan dalam mendidik anak. Keteladanan Luqman Al- 
Hakim dalam mendidik anak ini telah diabadikan dalam Al-Qur'an agar menjadi contoh dan pedoman bagai umat sesudahnya dalam mendidik. Tersebut dalam Surah Luqman ayat 12-19, Allah SWT berfirman:

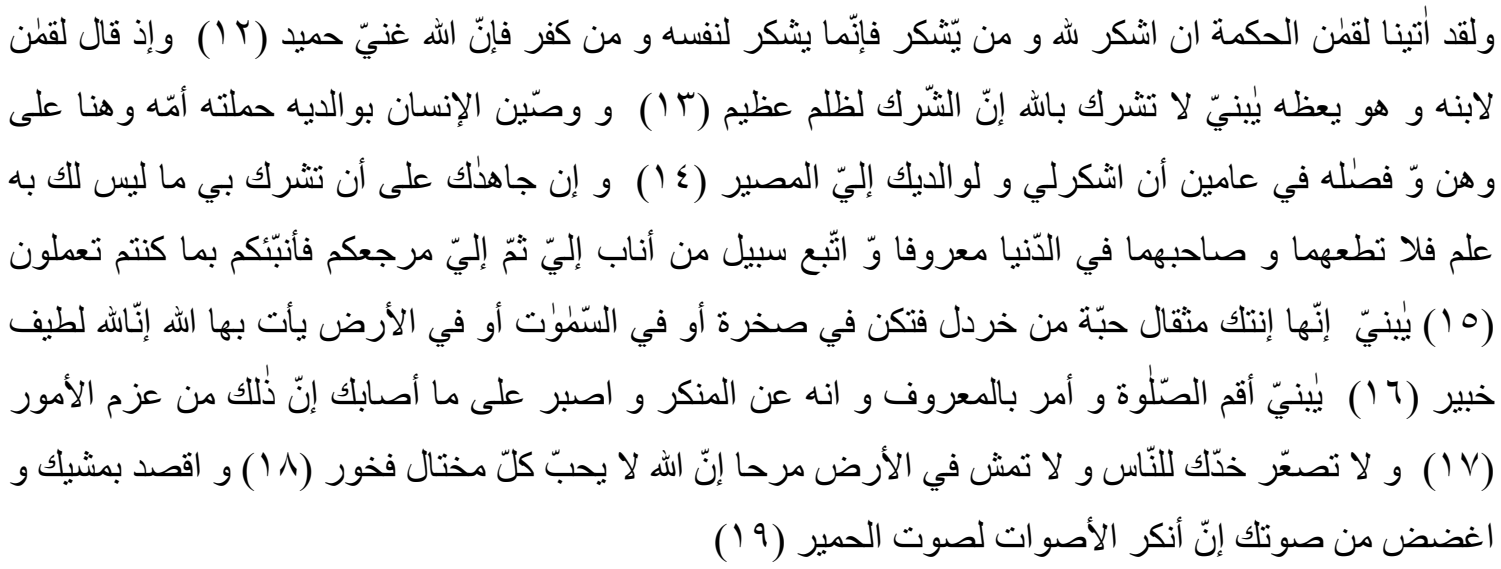

Artinya:

12. Dan Sesungguhnya telah Kami berikan hikemat kepada Luqman, Yaitu: "Bersyukurlah kepada Allah. dan barang siapa yang bersyukur (kepada Allab), Maka Sesunggubnya ia bersyukur untuk dirinya sendiri; dan barangsiapa yang tidak bersyukur (kufur), maka sesunggubnya Allah Maha Kaya lagi Maha Terpuji".

13. Dan (ingatlah) ketika Luqman berkata kepada anaknya, di waktu ia memberi pelajaran kepadanya: "Hai anakku, janganlah kamu mempersekutukan Allah, Sesunggubnya mempersekutukan (Allah) adalah benar-benar kezaliman yang besar".

14. Dan Kami perintabkan kepada manusia (berbuat baik) kepada dua orang ibu-bapanya; ibunya telah mengandungnya dalam Keadaan lemah yang bertambah-tambah, dan menyapihnya dalam dua tahun. bersyukurlah kepadaku dan kepada dua orang ibu bapakmu, hanya kepada-Kulah kembalimu.

15. Dan jikea keduanya memaksamu untuk mempersekutukan dengan aku sesuatu yang tidak ada pengetahuanmu tentang itu, Maka janganlah kamu mengikuti keduanya, dan pergaulilah keduanya di dunia dengan baik, dan ikutilah jalan orang yang kembali kepada-Ku, kemudian hanya kepada-Kulah kembalimu, Maka Kuberitakan kepadamu apa yang telah kamu kerjakan.

16. (Luqman berkata): "Hai anakku, Sesunggubnya jika ada (sesuatu perbuatan) seberat biji sawi, dan berada dalam batu atau di langit atau di dalam bumi, niscaya Allah akan mendatangkannya (membalasinya). Sesunggubnya Allah Maha Halus lagi Maha mengetahui.

17. Hai anakku, dirikanlah shalat dan surublah (manusia) mengerjakan yang baik dan cegablah (mereka) dari perbuatan yang mungkar dan bersabarlah terhadap apa yang menimpa kamu. Sesunggubnya yang demikian itu Termasuk hal-hal yang diwajibkan (oleh Allah).

6 | Jurnal Auladuna

Vol.Dl. №.QZ. April 2019 
18. Dan janganlah kamu memalingkan mukamu dari manusia (karena sombong) dan janganlah kamu berjalan di muka bumi dengan angkuh. Sesunggubnya Allah tidak menyukai orang-orang yang sombong lagi membanggakan diri.

19. Dan sederhanalab kamu dalam berjalan dan lunakeanlah suaramu. Sesunggubnya seburuk-buruk suara ialah suara keledai.

\section{Isi kandungan surat Luqman :}

Ayat 12 menguraikan tentang salah seorang yang bernama Luqman yang dianugerahi oleh Allah SWT hikmah, sambil menjelaskan beberapa butir hikmah yang pernah beliau sampaikan kepada anaknya. Para ulama mengajukan aneka keterangan tentang makna hikmah. Antara lain bahwa hikmah berarti "Mengetahui yang paling utama dari segaala sesuatu, baik pengetahuan, maupun perbuatan. Ia adalah ilmu amaliah dan amal ilmiah. Ia adalah ilmu yang didukung oleh amal, dan amal yang tepat dan didukung oleh ilmu.

Di ayat 13 dilukiskan pengalaman hikmah itu oleh Luqman, serta pelestariannya kepada anaknya. Ini pun mencerminkan kesyukuran beliau atas anugerah itu.

Menurut Al-Biqa'I, ayat 14 bagaikan menyatakan: Luqman menyatakan hal itu kepada anaknya sebagai nasihat kepadanya, padahal Kami telah mewasiatkan anaknya dengan wasiat itu seperti apa yang dinasihatkannya menyangkut hak Kami. Thahir Ibn 'Asyur berpendapat bahwa jika kita menyatakan bahwa Luqman bukan seorang Nabi, maka ayat ini adalah sisipan yang sengaja diletakkan setelah wasiat Luqman yang lalu tentang keharusan mengesakan Allah dan mensyukuri-Nya. Allah menggambarkan betapa Dia sejak dini telah melimpahkan anugerah kepada hamba-hamba-Nya dengan mewasiatkan anak agar berbakti kepada orang tuanya. Di ayat 14 tidak menyebutkan jasa bapak, tetapi lebih menekankan jasa ibu. Ini disebabkan karena ibu berpotensi untuk tidak dihiraukan oleh anak karena kelemahan ibu berbeda dengan bapak. Di sisi lain, "peranan bapak" dalam konteks kelahiran anak lebih ringan dibanding dengan peranan ibu. Setelah pembuahan, semua proses kelahiran anak dipikul sendirian oleh ibu.Bukan hanya sampai masa kelahirannya, tetapi berlanjut dengan penyusuan, bahkan lebih dari itu. Memang ayah pun bertanggung jawab menyiapkan dan membantu ibu agar beban yang dipikulnya tidak terlalu berat, tetapi ini tidak langsung menyentuh anak, berbeda dengan peranan ibu.

Vol.DI. No.QZ2. April 2019

7 | Jurnal Auladuna 


\section{Siti Mutmainah}

Ayat 15 menjelaskan tentang pengecualian menaati perintah kedua orangtua, sekaligus menggaris bawahi wasiat Luqman kepada anaknya tentang keharusan meninggalkan kemusyrikan dalam bentuk serta kapan dan dimana pun. Kewajiban menghormati dan menjalin hubungan baik dengan ibu bapak, menjadikan sementara ulama berpendapat bahwa seorang anak boleh saja membelikan buat ibu bapaknya yang kafir dan fakir minuman keras kalau mereka telah terbiasa dan senang meminumnya, karena meminum minuman keras buat orang kafir bukanlah sesuatu yang munkar.

Ayat ini mengandung pesan, yang pertama, bahwa mempergauli dengan baik itu hanya dalam urusan keduniaan, bukan keagamaan. Yang kedua, bertujuan meringankan beban tugas itu, karena ia hanya untuk smentara yakni selama hidup di dunia yang hari-harinya terbatas, sehingga tidak mengapalah memikul beban kebaktian kepada-Nya. Dan yang ketiga, bertujuan menghadapkan kata dunia dengan hari kembali kepada Allab yang dinyatakan di atas dengan kalimat hanya kepada-Ku kembali kamu. ${ }^{3}$

Ayat 16 menguraikan tentang kedalaman ilmu Allah swt., yang diisyaratkan pula oleh penutup ayat lalu dengan pernyataan-Nya. Dalam ayat ini terdapat kata Lathif yang bermakna lembut, halus, atau kecil. Dari makna ini kemudian lahir makna ketersembunyian dan ketelitian. Imam al-Ghazali menjelaskan bahwa yang berhak menyandang sifat ini adalah yang mengetahui perincian kemashalatan dan seluk beluk rahasianya, yang kecil dan yang halus, kemudian menempuh jalan untuk menyampaikannya kepada yang berhak secara lemah lembut bukan kekerasan. Pada akhirnya tidak keliru jika dikatakan bahwa Allah Lathif, kerena Dia selalu menghendaki untuk makhluk-Nya kemaslahatan dan kemudahan lagi menyiapkan sarana dan prasarana guna kemudahan meraihnya.

Dalam konteks ayat ini, agaknya perintah berbuat baik, apalagi kepada orangtua yang berbeda agama, merupakan salah satu bentuk dari Luthf Allah swt. Karena betapapun perbedaan atau perselisihan antara anak dan ibu bapak, pasti hubungan darah yang terjalin antara mereka tetap berbekas di hati masing-masing. Dan dapat disimpulkan bahwa ayat ini menggambarkan Kuasa Allah melakukan perhitungan atas amal-amal perbuatan manusia di akhirat nanti. Demikian, melalui keduanya tergabung uraian tentang keesaan Allah dan

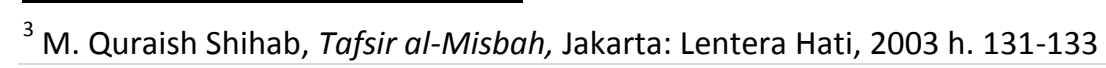

8 I Jurnal Auladuna

Vol.DI. No.D2. April 2019 
keniscayaan hari kiamat. Dua prinsip dasar akidah Islam yang sering kali mewakili semua akidahnya. ${ }^{4}$

Ayat 17 menjelaskan tentang hal-hal yang berkaitan dengan amal-amal shaleh yang puncaknya adalah shalat, serta amal-amal kebajikanyang tercermin dalam amr ma'ruf dan nabi munkar, juga nasihat berupa perisai yang membentengi seseorang dari kegagalan yaitu sabar dan tabah. Kata 'åm dari segi bahasa bararti keteguhan hati dan tekad untuk melakukan sesuaatu. Kata ini berpatron mashdar, tetapi maksudnya adalah objek, sehingga makna penggalan ayat itu adalah shalat, amr ma'ruf dan nabi munkar - serta kesabaran - merupakan hal-hal yang telah diwajibkan oleh Allah untuk dibulatkan atasnya tekad manusia. Thabathaba'i tidak memahami kesabaran sebagai salah satu yang ditunjuk oleh kata yang demikian itu, karena menurutnya kesabaran telah masuk dalam bagian azm. Maka atas dasar itu, bersabar yakni menahan diri termasuk dalam 'azm dari sisi bahwa 'aẓm yakni tekad dan keteguhan akan terus bertahan selama masih ada sabar. Dengan demikian kesabaran diperlukan oleh tekad serta kesinambungannya. ${ }^{5}$

Naasihat Luqman pada ayat 18 dan 19 berkaitan dengan akhlak dan sopan santun berinteraksi dengan sesama manusia. Materi pelajaran aqidah, beliau selingi dengan materi pelajaran akhlak, bukan saja agar peserta didik tidak jenuh dengansatu materi, tetapi juga untuk mengisyaratkan bahwa ajaran akidah dan akhlaq merupakan satu kesatuan yang tidak dapat di pisahkan.

Beliau menasihati anaknya dengan berkata: Dan wahai anakku, di samping butir-butir nasihat yang lalu, janganlah juga engkau berkeras memalingkan pipimu yakni mukamu dari manusia siapapun dia - didorong oleh penghinaan dan kesombongan. Tetapi tampillah kepada setiap orang dengan wajah berseri penuh rendah hati. Dan bila engkau melangkah, janganlab berjalan di muka bumidengan angkuh, tetapi berjalanlah dengan lemah lembut penuh wibawa. Sesungguhnya Allah tidak menyukai yakni tidak melimpahkan anugerahkasih sayang-Nya kepada orang orangyang sombong lagi membanggakan diri. Dan bersikap sederhanalah dalam berjalanmu, yakni jangan membusungkan dada dan jangan juga merunduk bagaikan orang sakit. Jangan berlari tergesagesa dan jangan juga sangat perlahan menghabiskan waktu. Dan lunakkanlah suaramu sehingga

\footnotetext{
${ }^{4}$ Ibid, hal. 133-136

${ }^{5}$ M. Quraish Shihab, Tafsir al-Misbah, Jakarta: Lentera Hati, 2003 h. 133-138

Vol.DI. No.D2. April 2019

9 | Jurnal Auladuna
} 


\section{Siti Mutmainah}

tidak terdengar kasar bagaikan teriakan keledai. Sesunggubnya sebukruk-buruk suara ialah suara keledai karena awalnya siulan yang tidak menarik dan akhirnya tarikan nafas yang buruk.

\section{Nasihat Luqman}

Di antara nasihat Luqman yang terdapat dalam surah Luqman ialah:

- Jangan mempersekutukan Allah (Luqman [31]:13).

- Berbuat baik kepada dua orang ibu-bapanya (Luqman [31]:14).

- Sadar akan pengawasan Allah (Luqman [31]:16).

- Dirikan salat (Luqman [31]:17).

- Perbuat kebajikan (Luqman [31]:17).

- Jauhi kemungkaran (Luqman [31]:17).

- Sabar menghadapi cobaan dan ujian (Luqman [31]:17).

- Jangan sombong (Luqman [31]:19).

Keutamaan Luqman adalah beliau menggabungkan hikmah dan syukur menjadi karakter pendidik yang unggul. Karakter di mana ketika seorang hamba yang pandai berhikmah maka dia akan menjadi pribadi yang tenang akan setiap masalah karena tinggi ilmu yang dimiliki sehingga mudah saja memikirkan jalan keluar yang terbaik, bukan karena melupakannya. Syukur merupakan perilaku yang senantiasa meningkatkan kapasitas diri ketika nikmat di beri atasnya dan akan terus meningkatkan kapasitasnya dalam segi ibadah maupun muamalah ketika nikmat itu di tambah oleh Allah Swt.

Luqman dalam pendidikan anak-anaknya mengutamakan pendidikan aqidah, di mana itulah penyelamat anak-anaknya ketika suatu tidak dapat menolongnya selain pertolongan Allah Swt dikarenakan sangat sayang kepada hamba-hamba-Nya yang bertaqwa. Allah Swt sangatlah pencemburu terhadap hamba-hamba-Nya apabila seorang manusia berbuat zhalim seperti syirik, yaitu menempatkan sifat ketuhanan Allah bukan pada tempatnya, manusia menyembah kepada selain Allah. Jangankan berbuat syirik, kita menunda-nunda waktu shalat pun kita sudah menduakan Allah. Seperti pesan Luqman terhadap anak-anaknya dalam surat Luqman ayat 13, "Dan (ingatlah) ketika Luqman berkata kepada anaknya, di waktu ia memberi pelajaran kepadanya: "Hai anakku, janganlah kamu mempersekutukan Allah, sesungguhnya mempersekutukan (Allah) adalah benar-benar kezhaliman yang besar”. 
Pendidikan akhlak pun tak luput dari pengajaran Luqman terhadap anak-anaknya, seperti dalam surat Luqman ayat 14, yaitu "Dan Kami perintahkan kepada manusia (berbuat baik) kepada dua orang ibu-bapaknya; ibunya telah mengandungnya dalam keadaan lemah yang bertambah-tambah, dan menyapihnya dalam dua tahun. Bersyukurlah kepadaKu dan kepada dua orang ibu bapakmu, hanya kepada-Kulah kembalimu”. Pada ayat ini Allah mengisahkan pembelajaran oleh Luqman terhadap anak-anaknya tentang keutamaan berbaktinya seorang anak karena kesusahan ayah dan ibunya saat anak masih dalam kandungan, terlebih ibu yang susah yang bertambah-tambah dan kita diwajibkan bersyukur kepada Allah dan kedua orang tua dengan berbakti kepada keduanya. Berbakti kepada orang tua termasuk meminta izin terhadap apa yang ingin kita lakukan dalam skala makro, seperti ingin menikah, bekerja, maupun pindah ke tempat baru.

Adapun pada ayat setelahnya yaitu Luqman ayat 15 , "Dan jika keduanya memaksamu untuk mempersekutukan dengan Aku sesuatu yang tidak ada pengetahuanmu tentang itu, maka janganlah kamu mengikuti keduanya, dan pergaulilah keduanya di dunia dengan baik, dan ikutilah jalan orang yang kembali kepada-Ku, kemudian hanya kepada-Kulah kembalimu, maka Kuberitakan kepadamu apa yang telah kamu kerjakan”. Poin yang terpenting di ayat ini adalah jika orang tua mengajak kepada kemaksiatan maka tidak boleh mengikuti, namun kita tetap berkewajiban bergaul dengan baik terhadap orang tua. Contoh terbaik untuk menggambarkan aplikasi ayat ini adalah kisah nabi Ibrahim ketika menasihati ayahnya yang pembuat patung untuk disembah oleh masyarakatnya, beliau tidak mengikuti langkah ayahnya dan tetap memberi nasihat dan berdiskusi dengan ayahnya mengenai perbuatan maksiat yang ayahnya lakukan. Mungkin kita sering bertanya, kenapa masih banyak anak yang perilakunya tidak baik.

Pendidikan konsekuensi terhadap tindakan pun menjadi penting agar tidak sembarangan dalam melakukan suatu tindakan, dalam surat Luqman ayat 16, yaitu "(Luqman berkata): "Hai anakku, sesungguhnya jika ada (sesuatu perbuatan) seberat biji sawi, dan berada dalam batu atau di langit atau di dalam bumi, niscaya Allah akan mendatangkannya (membalasinya). Sesungguhnya Allah Maha Halus lagi Maha Mengetahui”. Dalam ayat ini terdapat konsep keimanan pada hari akhir. Dari konsep tersebut butuh dua pemahaman untuk menjalankannya dengan baik. Pertama adalah Ihsan, yaitu sikap muraqabatullah di mana manusia itu berada, maka Allah akan mengetahui apa yang dia lakukan maupun niat yang ada dalam hatinya. Kedua 


\section{Siti Mutmainah}

adalah tanggung jawab Ilahiyah, di mana seseorang harus bertanggung jawab akan tindakannya selama di dunia di hadapan Allah kelak.

Menjadi shalih/shalihah bukanlah hal yang biasa jika dia saja yang menjadi shalih/shalihah tanpa merubah lingkungan sekitarnya. Terdapat dalam surat Luqman ayat 17, "Hai anakku, dirikanlah shalat dan suruhlah (manusia) mengerjakan yang baik dan cegahlah (mereka) dari perbuatan yang mungkar dan bersabarlah terhadap apa yang menimpa kamu. Sesungguhnya yang demikian itu termasuk hal-hal yang diwajibkan (oleh Allah)". Kewajiban ini merupakan konsep tanggung jawab secara konstitusi antara Allah dengan hamba-Nya yang bertaqwa. Konsep pertama yaitu, seorang hamba yang bertaqwa senantiasa melakukan amar ma'ruf dan nahi munkar, namun melakukan ini pada zaman sekarang butuh berjamaah karena selain godaan banyak tapi juga fitnah akan deras mengalir ke orang yang melakukan nahi munkar. Kedua adalah sabar atas keadaan yang menimpa dirinya, rasa sabar inilah yang membuat manusia semakin tegar dalam menghadapi cobaan dalam mengimplementasikan ilmu yang dimiliki.

Bagian terakhir dalam pendidikan akhlak yang diajarkan Luqman kepada kita terdapat dalam ayat ke 18 dan 19, "Dan janganlah kamu memalingkan mukamu dari manusia (karena sombong) dan janganlah kamu berjalan di muka bumi dengan angkuh. Sesungguhnya Allah tidak menyukai orang-orang yang sombong lagi membanggakan diri. Dan sederhanalah kamu dalam berjalan dan lunakkanlah suaramu. Sesungguhnya seburuk-buruk suara ialah suara keledai”. Sikap sombong di sini adalah merendahkan orang lain dan tidak mau mendengarkan kebenaran, alangkah kasihan orang tersebut karena Allah akan mengazabnya dengan siksa yang pedih karena yang patut sombong hanya Allah SWT."Perilaku seorang muslim yaitu apabila ia berkata maka kata-kata yang keluar adalah kata-kata yang baik lagi menyejukkan dan apabila bertindak maka tindakannya tepat pada sasaran dan tidak terburu-buru”.

\section{Diksi yang Digunakan dalam Mengasuh Anak dalam Al-Quran}

Menurut Kamus Besar Bahasa Indonesia, diksi adalah pilihan kata yang tepat dan selaras (dalam penggunaannya) untuk mengungkapkan gagasan sehingga diperoleh efek tertentu (seperti apa yang diharapkan). ${ }^{6}$ Pemilihan diksi yang tepat dalam suatu wacana akan mempermudah pembaca atau lawan tutur untuk menangkap makna dari penulis atau

${ }^{6} \mathrm{KBBI}(2002: 264)$

12 | Jurnal Auladuna

Vol.DI. No.DZ. April 
pembicara. Teori ini juga berlaku dalam mengasuh anak. Dalam Al-Quran nasihat orang tua terhadap anak banyak dicontohkan dalam surat Lukman. Berikut ini diksi yang digunakan dalam mengasuh anak dalam Al-Quran:

\section{Negasi jangan}

Negasi menurut KBBI adalah penyangkalan atau peniadaan. Dalam istilah linguistik, negasi adalah sebutan untuk kata sangkalan. Ada empat kata sangkalan dalam bahasa Indonesia, yaitu tidak, bukan, belum, dan jangan. Empat kata sangkalan ini digunakan dalam situasi yang berbeda. ${ }^{7}$

Lukman dalam Al-Quran menasihati anaknya dengan banyak menggunakan negasi jangan. Hal ini membuktikan kata negasi jangan lebih efektif dalam mendidik anak. Meskipun saat ini banyak ahli mengatakan bahwa penggunaan negasi jangan seharusnya diganti dengan negasi yang lain. Namun sebagai seorang muslim sebaiknya kita percaya bahwa ajaran AlQuran jauh lebih baik dari lainnya.

\section{Kata syukur}

Syukur adalah rasa terima kasih kepada Allah. ${ }^{8}$ Oleh sementara ulama syukur didefinisikan dengan memfungsikan anugerah yang diterima sesuai dengan tujuan penganugerahannya, yaitu menggunakan nikmat sebagaimana kehendak Pemberi Anugerah, sehingga penggunaannya itu mengarah sekaligus tertuju kepada ridhanya Pemberi Anugerah. Tentu saja untuk maksud ini, yang bersyukur perlu mengenali siapa Penganugerah (Allah SWT), mengetahui nikmat-Nya, serta fungsi dan cara menggunakan nikmat itu sebagaimana yang dikehendaki-Nya, sehingga yang dianugerahi nikmat itu benar-benar dapat menggunakannya sesuai dengan apa yang dikehendaki oleh sang Pemberi Anugerah.

3. Kata kufur

Arti kata kufur yaitu tidak percaya kepada Allah dan Rasul-Nya.9" "kufur", menurut istilah syariat, adalah tidak beriman kepada Allah dan Rasul-Nya, baik dengan mendustakannya atau tidak mendustakannya. Namun kufur yang dimaksud dalam surat Lukman ayat 12 yaitu tidak bersyukur atas nikmat yang Allah berikan.

\footnotetext{
${ }^{7}$ https://kbbi.web.id

${ }^{8}$ Ibid.

${ }^{9}$ Ibid.

Vol.DI. №.GZ. April 2019 


\section{Siti Mutmainah}

\section{Kata Syirik}

Syirik artinya penyekutuan Allah dengan yang lain, misalnya pengakuan kemampuan ilmu daripada kemampuan dan kekuatan Allah, pengabdian selain kepada Allah Taala dengan menyembah patung, tempat keramat, dan kuburan, dan kepercayaan terhadap keampuhan peninggalan nenek moyang yang diyakini akan menentukan dan mempengaruhi jalan kehidupan. ${ }^{10}$ Luqman memulai nasehatnya dengan menekankan perlunya menghindari syirik (QS. Luqman: 13): "Hai anakku, janganlah kamu mempersekutukan Allah, Sesunggubnya mempersekutukan (Allah) adalah benar-benar kezaliman yang besar." Larangan ini sekaligus mengandung pengajaran tentang wujud dan ke-Esaan Allah. Dalam mendidik anak hal pertama dan paling utama yang harus didahulukan adalah menanamkan nilai-nilai 'aqidab atau pendidikan tauhid. Redaksi pesan yang berbentuk larangan, "jangan mempersekutukan Allab" untuk menekankan perlunya meninggalkan sesuatu yang buruk sebelum melaksanakan yang baik. Memang, menyingkirkan keburukan lebih utama daripada memperbanyak kebajikan dan seburuk-buruknya perkara itu adalah syirik (menyekutukan Allah).

\section{Kata zalim}

Zalim artinya bengis; tidak menaruh belas kasihan; tidak adil; kejam. ${ }^{11}$ Dalam ajaran Islam adalah meletakkan sesuatu/ perkara bukan pada tempatnya. Orang yang berbuat zalim disebut zalimin dan lawan kata dari zalim adalah adil. Penggunaan kata zalim yang digunakan untuk menasihati dalam Al-Quran berkaitan dengan kata syirik. Dalam QS. Lukman ayat 13 disebutkan bahwa Lukman melarang anaknya untuk tidak berbuat syirik karena perbuatan tersebut adalah perbuatan yang zalim.

6. Kata Berbakti

Berbakti artinya tunduk dan hormat; perbuatan yang menyatakan setia (kasih, hormat, tunduk). ${ }^{12}$ Dalam surat Luqman ayat 14 menjelaskan pentingnya penghormatan dan kebaktian kepada kedua orang tua itu sehingga menempati posisi kedua setelah pengagungan kepada Allah SW'T. Al-Qur'an sering kali menggandengkan perintah menyembah Allah dan perintah berbakti kepada kedua orang tua.

7. Kata Shalat

\footnotetext{
${ }^{10}$ https://kbbi.web.id

${ }^{11} \mathrm{Ibid}$.

${ }^{12}$ Ibid.
}

14 | Jurnal Auladuna 2019 
Shalat merujuk kepada ibadah pemeluk agama Islam. ${ }^{13}$ Luqman melanjutkan nasehat kepada anaknya dengan nasehat mendirikan shalat. Beliau berkata: "Hai anakku, dirikanlah shalat dan surublah (manusia) mengerjakan yang baik dan cegablah (mereka) dari perbuatan yang mungkar dan bersabarlah terhadap apa yang menimpa kamu. Sesunggubnya yang demikian itu Termasuk hal-hal yang diwajibkan (oleh Allab).” (Qs. Luqman ayat 17).

8. Kata ma'ruf dan kata munkar

Ma'ruf adalah perbuatan baik. ${ }^{14}$ Apa yang baik menurut pandangan masyarakat umum dan telah mereka kenal luas sedangkan munkar adalah sesuatu yang dinilai buruk oleh mereka serta bertentangan dengan nilai-nilai Ilahi. Menyuruh mengerjakan ma'ruf mengandung pesan untuk mengerjakannya, karena tidaklah wajar menyuruh sebelum diri sendiri mengerjakannya. Demikian juga melarang ke-munkar-an, munkar artinya durhaka (melanggar perintah Tuhan). ${ }^{15}$ Luqman tidak memerintahkan anaknya melaksanakan ma'ruf dan menjauhi munkar, melainkan memerintahkannya untuk menyuruh kepada yang ma'ruf dan mencegah yang munkar. Di sisi lain, hal ini juga bermakna membiasakan diri anak untuk berbuat sesuatu, dan melaksanakan tuntutan amar ma'ruf nahi munkar yang dapat menumbuhkan jiwa kepemimpinan serta kepedulian sosial pada dirinya.

9. Kata Sabar

Sabar artinya tahan menghadapi cobaan (tidak lekas marah, tidak lekas putus asa, tidak lekas patah hati); tabah. ${ }^{16}$ Karena orang yang bersabar berarti dia sedang bertahan, menahan diri pada satu sikap. Seseorang yang sabar akan menahan diri, dan untuk itu ia memerlukan kekukuhan jiwa dan mental agar dapat mencapai ketinggian derajat yang diharapkannya. Sabar adalah menahan gejolak nafsu demi mencapai yang baik atau yang terbaik, keteguhan dan tekad akan terus ada selama masih ada kesabaran.

10. Kata sombong

Sombong artinya menghargai diri secara berlebihan; congkak; pongah. ${ }^{17}$ Nasehat terhadap anak agar tidak sombong terdapat dalam QS. Luqman ayat 18-19. Luqman Al-Hakim

\footnotetext{
${ }^{13}$ Ibid.

${ }^{14}$ https://kbbi.web.id

${ }^{15}$ Ibid.

${ }^{16} \mathrm{Ibid}$.

${ }^{17}$ Ibid.
} 


\section{Siti Mutmainah}

mengatakan: "Wahai anakku, jangan engkau berkeras memalingkan mukamu dari manusia, karena penghinaan dan kesombongan. Tampillah dihadapan setiap orang dengan wajah yang berseri penuh rendah hati. Bila engkau melangkah maka janganlah berjalan di muka bumi dengan angkuh, tetapi berjalanlah dengan lemah lembut penuh tawadhu'. Sesungguhnya Alah tidak menyukai (yakni tidak menganugerahi kasih sayang) kepada orang-orang yang sombong lagi membanggakan diri. Bersikaplah sederhana dalam berjalan, yakni jangan membusungkan dada dan jangan pula merunduk bagaikan orang sakit. Jangan berlari tergesa-gesa dan jangan juga sangat perlahan-lahan menghabiskan waktu. Dan lunakkanlah suaramu sehingga tidak terdengar kasar bagaikan teriakan keledai.

11. Kata sederhana

Sederhana artinya bersahaja, tidak berlebih-lebihan. ${ }^{18}$ Dalam QS. Lukman ayat 19 disebutkan: "Dan sederbanalah kamu dalam berjalan dan lunakkanlah suaramu. Sesunggubnya seburukburuk suara ialah suara keledai." Jadi dalam ini Lukman menasihati anaknya untuk tidak hidup berlebih-lebihan, ia harus sederhana dalam kehidupannya.

12. Kata lunak

Arti kata lunak yaitu lembut. ${ }^{19}$ Kata ini juga terdapat dalam QS. Lukman ayat 19. Lukman mengajarkan pada anaknya untuk tidak mengeraskan suara. Seorang yang mengeraskan suara identik dengan orang yang sombong dan merendahkan orang lain. Ia senantiasa berkata kasar dan membentak.

\section{E. Kesimpulan}

Sudah seharusnya orang tua memelihara dan mengasuh anak dengan baik sesuai dengan amanah yang diberikan Allah. Anak akan tumbuh dengan memiliki sifat-sifat yang baik dalam pemeliharaan dan pengasuhan yang baik. Dalam hal ini orang tua harus menjadi teladan bagi anak-anaknya baik tingkah laku dan ucapannya. Dalam penelitian ini ditekankan pada ucapan atau cara berbicara orang tua yang harus menggunakan bahasa yang baik dalam berkomunikasi dengan anak, karena bahasa sangat berpengaruh dalam tumbuh kembang anak. Salah satu penggunaan bahasa yang baik yaitu dengan memilih diksi yang tepat. Pemilihan diksi yang tepat

${ }^{18}$ https://kbbi.web.id

${ }^{19}$ Ibid.

16 | Jurnal Auladuna

2019

Vol.DI. No.D2. April 
dalam suatu wacana akan mempermudah pembaca atau lawan tutur untuk menangkap makna dari penulis atau pembicara. Teori ini juga berlaku dalam mengasuh anak.

Dalam Al-Quran nasihat orang tua terhadap anak banyak dicontohkan dalam surat Lukman yang didalamnya terdapat diksi atau pilihan kata sebagai berikut: 1) kata jangan, 2) kata syukur, 3) kata khufur, 4) kata syirik, 5) kata zalim, 6) kata berbakti, 7) kata shalat, 8) kata ma'ruf, 9) kata munkar, 10) kata sombong, 11) kata sederhana, 12) kata lunak.

\section{Daftar Referensi}

Abdurrahman, Muhammad Yusuf bin. 2013. 3 Tabun Hafal Al-Qur'an. Yogyakarta: Sabil.

Ahmad, Ukasyah Habibu. 2015. Didiklah Anakmu Ala Rasulullah. Yogyakarta: Saufa.

Al-Jailani, Syekh Abdul Qadir. 2010. Sirr al-Asrar fi Ma Yabtaj Ilaih al-Abrar. Yogyakarta: DIVA Press.

Apprilia, Yesie. 2014. Gentle Birth Balance: Persalinan Holistik Mind, Body, and Soul. Bandung: Qanita.

Baihaqi, A. K. 1996. Mendidik Anak dalam Kandungan. Jakarta: Raja Grafindo Persada.

Buchori, Ihsan Baihaqi Ibnu. 2010. Yuk, Jadi Orang Tua Shalil! Sebelum Meminta Anak Shalih. Bandung: Mizania.

Istadi, Irawati. 2005. Agar Hadiah dan Hukuman Efektif. Jakarta: Tanpa Penerbit.

Quthb, Muhammad. 1993. Sistem Pendidikan Islam. Bandung: Tanpa Penerbit.

Rahmi, Mutiarani Nur. 2005. Pendidikan Janin Menurut F. Rene Van De Carr, M.D. dan Marc Lehrer, Ph.D. dalam Perspektif Pendidikan Islam. Semarang: IAIN Walisongo.

Rusyd, Raisya Maula Ibnu. 2011. Tebas Habis Semua Jenis Dosa Orang Tua pada Anaknya. Yogyakarta: DIVA Press.

Shihab, M. Quraish, 2003. Tafsir al-Misbah. Jakarta: Lentera Hati. 